\title{
Canto de xangô: uma tópica afro-brasileira
}

Canto de xangô: an African-Brazilian topic

Juliana Ripke da Costa

juripke@hotmail.com 


\section{Resumo}

Este artigo pretende analisar e demonstrar as características e utilização de tópicas musicais afro-brasileiras dentro de algumas obras do compositor Heitor Villa-Lobos e outros compositores brasileiros como Camargo Guarnieri, Moacir Santos e Baden Powell. Desta forma, será feito o estudo, identificação e sistematização das principais características do tipo xangô proposto e identificado por Eero Tarasti na obra de Villa-Lobos, e de uma das tópicas mais utilizadas por Villa-Lobos, que aqui chamaremos de tópica canto de xangô, considerada pelo autor um arquétipo da qualidade de afro-brasileiro. Entendendo que a tópica é uma figura de representação, analisarei também como Villa-Lobos e posteriormente outros compositores brasileiros representaram a música e a cultura afro-brasileira em suas obras através do tipo xangô e da tópica canto de xangô. O papel desempenhado pelas tópicas musicais Afro-brasileiras serão abordados por meio de uma combinação de algumas técnicas analíticas e estratégias semióticas de significação; assim, será possível alcançar uma melhor compreensão da estrutura e do discurso musical. Este estudo destina-se a ajudar a nossa compreensão da cultura africana como parte formadora e intrínseca da cultura brasileira e da "brasilidade", reforçando a ideia de fusão cultural que permeia a cultura e a música brasileira.

Palavras-chave: Tópicas. Afro-brasileiro. Xangô. Villa-Lobos.

\section{Abstract}

This article aims to analyze and demonstrate the features and use of African-Brazilian musical topics within a some works of the composer Heitor Villa-Lobos and other Brazilian composers such as Camargo Guarnieri, Moacir Santos and Baden Powell. In this way, it will be done the study, identification and systematization of the main features of the xangô-type proposed and identified by Eero Tarasti in the his work about Villa-Lobos, and one of the most commonly used topics by Villa-Lobos, which here call the canto de xangô topic, considered by the author an archetype of the Afro-Brazilian quality. The topic is a figure of representation, and I will analyze as Villa-Lobos and later other Brazilian composers represented the Afro-Brazilian music and culture in his works through the xangô-type and canto de xangô topic. The role played by African-Brazilian musical topics will be approached by means of a combination of some analytical techniques and semiotic strategies of signification; thus, will be possible to achieve a better understanding of the musical structure and discourse. This study is intended to help our understanding of the African culture seen as a forming and intrinsic part of Brazilianness, reinforcing the idea of cultural fusion that permeates the culture and Brazilian music.

Keywords: African-Brazilian. Xangô. Villa-Lobos 


\section{Introdução}

Paulo de Tarso Salles explica que "a cultura brasileira está cheia de hibridismo, resultante do ato simbólico de "devoração" de culturas estrangeiras como meio de assimilação. Na música de Villa-Lobos, [por exemplo], isso foi a estratégia utilizada para desenvolver o seu próprio senso de estilo e linguagem" (SALLES, 2013b, p. 7). Esse hibridismo ${ }^{1}$, na música brasileira, ocorre em vários níveis e através de várias confluências, sendo uma delas a fusão da cultura africana com a cultura brasileira, trazendo o que chamamos de cultura afro-brasileira ${ }^{2}$.

Sodré explica que a sociedade brasileira se formou, no início do século de XVI, agrupando elementos americanos (indígenas), europeus (colonizadores portugueses) e africanos (escravos negros, trazidos principalmente da Costa Ocidental da Africa) (SODRÉ, 1983, p.120). Ainda segundo o mesmo autor, lá pelo fim do século XVIII, os nagôs ${ }^{3}$ (ou etnia iorubá) foram os últimos grupos africanos a se estabelecerem no Brasil. Os grupos dirigentes do Estado induziram a quebra de todos as organizações políticas, familiares, míticas, dentre outras, de todos os negros no Brasil. Apesar disso, os nagôs conseguiram reimplantar aqui, principalmente na Bahia, os "elementos básicos de sua organização de origem" (SODRE, 1983, p.121). Prandi e Vallado (2010, s.p.) descrevem que

os escravos recém-chegados eram trazidos não mais para o trabalho nas plantações e nas minas do interior, onde ficavam dispersos, mas sim nas cidades, onde eram encarregados de fazer todo o tipo de serviço urbano, morando longe de seus proprietários, vivendo em bairros com grande concentração de negros escravos e libertos, e tendo assim maior liberdade de movimento e organização, podendo se reunir nas irmandades católicas, com novas e amplas oportunidades para recriarem aqui a sua religião africana. Nascido da iniciativa de negros iorubás que se reuniam numa irmandade religiosa na igreja da Barroquinha, em Salvador, o primeiro templo iorubá da Bahia foi, emblematicamente, dedicado a Xangô. Seus ritos, que em grande parte reproduziam a prática ritualística de Oió, acabaram por moldar a religião que viria a se constituir no candomblé, e cuja estruturação hierárquica sacerdotal em grande parte reconstituía simbolicamente a organização da corte de Oió, isto é, a corte de Xangô (...). Emblemas que na África eram exclusivos do culto a Xangô foram generalizados entre nós para o culto de todos os orixás.

A presença da cultura africana e afro-brasileira na cultura brasileira é, porém, problematizável de várias formas. Renato Ortiz (2006) aborda isto de várias maneiras e trabalha com o conceito de que a cultura negra dentro da cultura brasileira teve diversas

1

Nestor Garcia Canclini (2011) é um dos pioneiros a pensar os conceitos de hibridismo cultural e culturas híbridas na América Latina.

$2 \quad$ Há alguns pesquisadores como Arthur Ramos (1940) que utilizam o termo negro brasileiro. Alguns autores utilizados neste trabalho como Priscila Paes (1989) e Sérgio Paulo Adolfo (2008) utilizam o termo afro-brasileiro para representar a fusão da cultura africana com a brasileira, onde as memórias de escravos africanos trazidos para o Brasil foram resignificadas e fundidas em território brasileiro. Além disso, o termo afro-brasileiro é um termo consenso e usual no meio acadêmico, no meio científico brasileiro, e o próprio Departamento de Antropologia da FFLCH (USP) tem uma linha de pesquisa com o nome "Antropologia das Populações Afro-Brasileiras e Africanas".

3 "Nagô é o nome genérico de todos os grupos originários do Sul e Centro do Daomé e do Sudoeste da Nigéria, portadores de uma tradição rica, derivada das culturas particulares dos diferentes reinos africanos de onde provieram" (SODRE, 1983, p.120). 
formas de ser representada tanto positiva quanto negativamente, trazendo também um panorama histórico dessa representação. O autor ainda explica que hoje existe uma ideologia de miscigenação democrática, e que isso é um produto recente na história brasileira, já que até a abolição da escravatura, o negro não existia enquanto cidadão, nem tampouco existia no plano literário. Em Guarani, por exemplo, um romance de 1857 do escritor brasileiro José de Alencar, os fundamentos da brasilidade são tratados de forma restritiva, pois a obra se ocupa da fusão do índio com o branco, deixando de lado o negro (que naquele momento era identificado e associado apenas à força de trabalho) (ORTIZ, 2006, p. 37).

Ortiz conta que os estudos sobre o negro iniciaram-se com Nina Rodrigues (na última década do século XIX), porém sob inspiração de teorias raciológicas (ORTIZ, 2006, p. 36). Em Casa Grande e Senzala (1933), porém, Gilberto Freyre traz um caráter positivo ao mestiço (ao invés do caráter negativo que antes era pregado), e então o brasileiro passa a ser definido como a combinação de traços de elementos africanos, indígenas e portugueses. Este era o mito das três raças, que se tornou senso comum no Brasil, celebrado em relações do cotidiano, ou em grandes eventos como carnaval e o futebol, fazendo entender que o que era mestiço era símbolo do nacional (ORTIZ, 2006, p. 41). Com isso, a cultura brasileira passou a ser mestiçamente definida como algo a ser preservado como garantia de particularidade e especificidade diante de outras nações, e não pelo atraso do país em relação à Europa definido pelos intelectuais brasileiros do final do século XIX (VIANNA, 1995, p. 63-64).

Em síntese, Renato Ortiz descreve três momentos importantes nas tentativas de construção da identidade (ou das identidades) brasileira, sendo o primeiro o "pessimismo" de Nina Rodrigues, o segundo o "otimismo" de Gilberto Freyre, e o terceiro o projeto do ISEB (Instituto Superior de Estudos Brasileiros), criado na década de 1950 e extinto após o golpe militar de 1964. O ISEB foi um projeto criado a partir das idéias de um nacionalismo anticolonialista, que propunha redefinir a problemática brasileira em termos de oposição ao colonialismo e tentava decifrar uma essência brasileira (ORTIZ, 2006, p. 128-130).

Vale lembrar que o mito das três raças trazido por Gilberto Freyre é citado aqui a fim de demonstrar o início do desenvolvimento da idéia de uma identidade brasileira em que o negro se fazia presente de forma positiva. Naquele momento em que surgiu, 0 mito das três raças possibilitou a todos se reconhecerem como nacionais (ORTIZ, 2006, p. 44). Estes estudos identitários, porém, continuaram e se desenvolveram por vários caminhos. $O$ conceito de raça começou a se dissolver e ser questionado. Munanga ${ }^{4}$ traz um exemplo disso explicando que, no século $X X$, as pesquisas biológicas e científicas chegaram à conclusão de que dois indivíduos considerados pertencentes a uma mesma raça podem ter conteúdos genéticos totalmente diferentes e distantes, sendo que uma característica que é considerada marca de uma raça pode ser também encontrada em outra. Assim, os estudiosos dessa área do conhecimento concluíram que o conceito de 
raça não pode ser aplicado a uma realidade biológica, mas que é um conceito inoperante que tenta explicar a diversidade humana. "Ou seja, biológica e cientificamente, as raças não existem" (MUNANGA, 2003, s.p.). O autor ainda explica que

a classificação da humanidade em raças hierarquizadas desembocou numa teoria pseudo científica, a raciologia, que ganhou muito espaço no início do século XX. Na realidade, apesar da máscara científica, a raciologia tinha um conteúdo mais doutrinário do que científico, pois seu discurso serviu mais para justificar e legitimar os sistemas de dominação racial do que como explicação da variabilidade humana. Gradativamente, os conteúdos dessa doutrina chamada ciência, começaram a sair dos círculos intelectuais e acadêmicos para se difundir no tecido social das populações ocidentais dominantes. Depois foram recuperados pelos nacionalismos nascentes como o nazismo para legitimar as exterminações que causaram à humanidade durante a Segunda guerra mundial. Podemos observar que o conceito de raça tal como o empregamos hoje, nada tem de biológico. É um conceito carregado de ideologia, pois como todas as ideologias, ele esconde uma coisa não proclamada: a relação de poder e de dominação. [...] o conteúdo dessas palavras é etno-semântico, político-ideológico e não biológico. (MUNANGA, 2003, s/p).

Atualmente, portanto, podemos ir das definições de diferenciação racial, e trazer o conceito de diferenciação étnica e cultural, ou seja, três etnias ou três culturas (com todas as suas multiplicidades e diversas subdivisões) que se fundiram e formaram a cultura brasileira, sem precisar nos ater aos conceitos de raça. Segundo Ortiz "a passagem do conceito de raça para o de cultura elimina uma série de dificuldades colocadas anteriormente a respeito da herança atávica do mestiço" (ORTIZ, 2006, p. 41), e assim "os movimentos negros atuais operam de [buscando] formas concretas de expressões culturais para interpretá-las e reinterpreta-las dentro de uma perspectiva mais ampla" (ORTIZ, 2006, p. 141). Munanga ainda completa dizendo que "o conteúdo da raça é morfo-biológico e o da etnia é sócio-cultural, histórico e psicológico" (MUNANGA, 2003, s.p.). Para Munanga, porém, a substituição do conceito de raça pelo de etnia não muda o racismo, sendo o termo etnia apenas mais cômodo para a utilização de racistas e não-racistas.

Como vemos, as questões da identidade nacional e o fluxo de terminologias como raça, cultura e etnia, são abordados por diversos autores e intelectuais em diversas épocas e de diversas formas. Segundo Renato Ortiz, "o tema da cultura brasileira e da identidade nacional é um antigo debate que se trava no Brasil. No entanto, ele permanence atual até hoje, constituindo uma espécie de subsolo estrutural que alimenta toda a discussão em torno do que é o nacional" (ORTIZ, 2006, p. 7). Ainda segundo o mesmo autor, os intelectuais que abordam o assunto da construção da identidade nacional agem como mediadores simbólicos pois fazem uma ligação entre o particular e o universal, o singular e o global, e ainda são essenciais pois "descolam as mnifestações de sua esfera particular e as articulam a uma totalidade que as transcende" (ORTIZ, 2006, p. 140-141). Podemos aqui, a título das análises musicais que serão feitas neste artigo, assumir a cultura afro-brasileira como já reconhecidamente presente na cultura brasileira e como parte formadora desta, apesar dos vários fluxos que permeiam a questão da identidade nacional brasileira e de todo o caminho percorrido pelos intelectuais e pelas pesquisas nesse sentido. 
Musicalmente falando, uma das ferramentas possíveis para análise de elementos afro-brasileiros dentro da música brasileira são as tópicas musicais. Tópicas são figuras retóricas dentro da música que representam e evocam uma memória de um senso comum dentro de um contexto cultural, a partir de convenções. Acácio Piedade explica que é possível usar "uma perspectiva baseada em tópicas para investigar o aspecto retórico nos estilos e gêneros musicais" (PIEDADE, 2013, p. 3). Sendo a tópica uma figura de representação, entendemos que "sua configuração aparente não está conforme à sua função real" (ANGENOT, 1984, p. 97) e nem precisa ser, necessariamente, uma representação literal do que está se referindo. A teoria das tópicas propõe trazer uma correlação entre estrutura e significado, ou seja, rediscutir o significado da obra a partir de sua relação com a estrutura musical. Isto ainda leva em consideração aspectos da interpretação pessoal dos compositores no uso de elementos estilísticos e identitários, sendo que as tópicas podem ser móveis e dinâmicas, sofrendo ações decorrentes de processos de hibridação cultural. Assim sendo, as tópicas constituem elementos comuns a uma cultura, mas também são elementos móveis, no sentido de sofrer as influências dos traços composicionais e idiomáticos de cada compositor.

Eero Tarasti faz uso do termo "Xangô-type themes" para designar trechos do Quarteto de cordas n. 4 e n. 6 de Villa-Lobos que pertencem ao paradigma de temas de tipo xangô (TARASTI, 1995, p. 304). Um pouco depois, Tarasti explica que a combinação de um tema de tipo xangô contra um acompanhamento sincopado de subdivisão quaternária é uma das mais comuns tópicas encontradas em Villa-Lobos. (TARASTI, 1995, p. 308), e é esta tópica que será analisada neste artigo. Consideraremos, portanto, para a presente análise, que esta tópica muita usada em Villa-Lobos se chamará tópica canto de xangô, pois a canção Xangô de Villa possui a representação sonora desta, com a melodia do Canto de Xangô (recolhida por Mário de Andrade) harmonizada em forma de ostinato sob uma harmonia estática, dentre outras características que falaremos mais adiante.

Verificaremos, no presente artigo, a ocorrência da tópica canto de xangô em algumas obras do compositor Villa-Lobos, que deu o primeiro passo desta utilização, bem como em outras obras do repertório da música brasileira em geral, tanto na música erudita quanto na música popular. Acácio Piedade (2013, p. 11) explica que:

[...] podemos aplicar a teoria das tópicas nesta comunidade cultural e historicamente situada que se entende enquanto uma nação, mesmo recortada por diversos e divergentes estilos internos. E daí se pode investigar a musicalidade brasileira, como qualquer outra. [...] Note-se que as tópicas flutuam acima da fronteira popular-erudito, e deste modo tratarei da musicalidade brasileira sem me ater a esta distinção.

Antes disso, porém, será feito um breve relato sobre a origem do estudo de tópicas musicais, suas principais características e a continuação destes estudos na América Latina e no Brasil. Adotarei, no presente artigo, a palavra tópica ${ }^{5}$ (e não tópico) por ser um termo já decorrente e utilizado por vários autores brasileiros, e por diferenciar da 
palavra tópico que tem uma utilização mais ampla e genérica na língua portuguesa.

\title{
O estudo de tópicas musicais - origem e continuação
}

O estudo de tópicas musicais ganhou interesse após a publicação do estudo sobre o estilo Clássico, de Leonard Ratner (1980). Ratner descreve que

\begin{abstract}
a partir dos seus contatos com devoção religiosa, poesia, drama, entretenimento, dança, cerimônia, militares, a caça e a vida das classes mais baixas, a música no início do século XVIII desenvolveu uma enciclopédia de figuras características, que formou um rico legado para compositores clássicos. Algumas dessas figuras foram associadas com vários sentimentos e afetos; outras tinham um sabor pitoresco. Elas são designadas aqui como tópicas - assuntos para o discurso musical. (RATNER, 1980, p.8, tradução desta autora).
\end{abstract}

Ainda segundo Ratner, as "tópicas aparecem como peças totalmente acabadas, ou seja, tipos, ou como figuras e progressões dentro de uma peça, ou seja, estilos" (RATNER, 1980, p. 9, tradução desta autora). Entendemos então, que Ratner separa as tópicas em duas categorias principais: tipos e estilos.

Através de seu livro, o autor propôs um estudo de tópicas musicais que traz um panorama das principais tópicas utilizadas no século XVIII, mostrando que a maioria das tópicas descritas e analisadas por ele são largamente utilizadas no decorrer deste século. Ratner relaciona o uso de tópicas ao estilo de vida, características e tradições européias daquele período. Diz, porém, que esta utilização é diferente no período barroco, pois a "música barroca tendia a desenvolver uma [única] ideia, afeto, ou tópica ao longo de uma peça, para manter a unidade através da consistência. Mas misturas e contrastes tornaram-se cada vez mais frequentes na música clássica" (RATNER, 1980, p. 26). Apesar destes contrastes de tópicas começarem a ser amplamente utilizados por Bach, segundo Ratner, "Mozart foi o maior mestre em misturar e coordenar tópicas em um curto espaço" (RATNER, 1980, p. 27). Hatten faz uma síntese das definições propostas por Ratner, e um esboço que, segundo ele, "exibe a hierarquia brusca implícita na apresentação de Ratner" (HATTEN, 1994, p. 75). Segue abaixo o esboço feito por Hatten a respeito das definições de Ratner : 6

\section{Códigos de sentimentos e paixões, ligados a:}
A. ritmo, movimento, tempo
B. intervalos
C. motivos usados para simbolizar afeto
II. Estilos, baseados em:

A. local, ocasião, situação 
1. eclesiástico/ estilo de igreja

2. estilo camerístico (galanterie)

3. teatral/ estilo operístico (relativo ao estilo camerístico)

B. grau de dignidade

1. alto estilo

2. médio estilo

3. baixo estilo

\section{Tópicas:}

A. tipos (peças totalmente finalizadas), como danças (minuetos, contradança, etc.) no alto, médio ou baixo estilo,

ou

B. estilos (figuras e progressões dentro de uma peça)

1. militar, caça

2. estilo cantante (ou de cantar)

3. abertura Francesa

4. musette, pastoral

5. música Turca

6. tempestade e tensão

7. sensibilidade, Empifindsamkeit

8. estrito, estilo erudito (vs. galant, ou estilo livre)

9. estilo fantasia

\section{Pictorialismo, pintura de palavras, e imitação de sons da natureza.}

Segundo Stefanovic (2010), em Ratner os tipos possuem maior homogeneidade, enquanto o estilo abrange um amplo espectro de fenômenos musicais, entre os quais podemos discernir imediatamente diferenças categoriais.

Além de Ratner, temos outros autores como Kofi Agawu (1991; 2009), Robert Hatten (1994; 2004), Raymond Monelle (2006) e Márta Grabócz (2009) que continuaram o estudo de tópicas musicais. Hatten expande o trabalho sobre tópicas trazendo um estudo sobre o que ele chama de conceitos-chave: "marcação, tipos de estilo, sinais estratégicos, tópicas, gêneros expressivos, e tropos"7 (HATTEN, 2004, p.1). Segundo Hatten, todos estes elementos analisados (elementos teóricos como escalas, acordes, unidades rítmicas, e também elementos interpretativos do discurso musical) em conjunto podem nos mostrar a "modelagem expressiva em todos os níveis da estrutura" (HATTEN, 2004, p.3). Ele ainda nos diz que as tópicas "possuem fortes correlações ou associações com significado expressivo" (HATTEN, 2004, p. 68) e começa a trazer relações entre a estrutura musical e seu significado. Hatten explica que 
na história da música, há o constante desenrolar de um processo de fricção e fusão de musicalidades: tópicas, estilos e gêneros contrastivos são reunidos e diluídos em outros, e estes, por sua vez, avançam, formando novas tópicas, estilos, gêneros, unidades com identidade própria que podem voltar a se fundir (PIEDADE, 2013, p. 6).

\section{Logo depois, o autor define que}

um conceito fundamental na retórica aristotélica é a noção de tópica, os topoï, elementos entendidos como lugares-comuns (em latim loci-communes) que são produzidos acerca de silogismos retóricos e dialéticos. Na oratória, os topoï formam as fontes que estão na base de um raciocínio. Na retórica, sobretudo na elocutio, distingue-se as figuras de palavras (ou tropos) das figuras de pensamento, as quais intervêm mais diretamente na organização do conjunto do discurso. (PIEDADE, 2013, p.7).

Abaixo podemos ver uma tabela com algumas definições de tópicas musicais segundo alguns autores relacionados ao assunto:

\begin{tabular}{|c|c|}
\hline \multicolumn{2}{|r|}{ Algumas definiçōes de tópicas musicais segundo cada autor } \\
\hline Autor & Definição \\
\hline Leonard Ratner & $\begin{array}{l}\text { Sobre o séc XVIII; tópicas "sāo figuras caracteristicas c assuntos para o discurso } \\
\text { musical". }\end{array}$ \\
\hline Robert Hatten & $\begin{array}{l}\text { Tópica é "uma correlação musical complexa originária de um tipo de música, usada } \\
\text { como parte de um trabalho maior". (HATTEN, 1994, p. 294-295, tradução desta } \\
\text { autora). } \\
\text { Define ainda que as tópicas "possucm fortes correlaçôes ou associações com } \\
\text { significado expressivo" (HATTEN, 2004, p. 68). }\end{array}$ \\
\hline Raymond Monelle & $\begin{array}{l}\text { Tópicas são "icones ou indices culturalmente consagrados [...]. A expressão } \\
\text { [tópica] é interpretada com referência a uma convenção, que seja uma regra efetiva } \\
\text { para toda a cultura contemporânea ou um traço do idioleto do compositor." } \\
\text { (MONELLE, 2000, p. 15). }\end{array}$ \\
\hline Melanie Plesch & Define as tópieas como um tipo de "emblema musical" (PLESCH, 1996, p. 57). \\
\hline Acacio Piedade & $\begin{array}{l}\text { "A teoria das tópicas pressupốe a visào da música como discurso, no qual se } \\
\text { manifestam figuras da retórica musical" (PIEDADE, 2013, p.7). }\end{array}$ \\
\hline Gabriel Moreira & $\begin{array}{l}\text { Define que a tópica é uma "construçäo musical objetiva que se configura como } \\
\text { significante - no sentido semiótico - ao comunicar um significado para uma } \\
\text { audiéncia informada desses signos culturais correntes" (MOREIRA, 2010, p. 231). }\end{array}$ \\
\hline
\end{tabular}

Fig. 1- Definições de tópicas musicais segundo alguns autores 
Dentro dos trabalhos dos autores brasileiros, podemos listar alguns exemplos de tópicas estudadas e analisadas por cada autor:

\begin{tabular}{||l|l||}
\hline \hline Autor & Tópicas \\
\hline \hline Acácio Piedade & $\begin{array}{l}\text { Brejeiro; Epoca-de-ouro; Nordestina; Floresta tropical; Indigena; } \\
\text { Caipiras. }\end{array}$ \\
\hline $\begin{array}{l}\text { Paulo de Tarso } \\
\text { Salles }\end{array}$ & Canto de Sabiá; Pictorialismo. \\
\hline $\begin{array}{l}\text { Rodolfo Coelho de } \\
\text { Souza }\end{array}$ & $\begin{array}{l}\text { Civilizado; Infantil; Selvagem; Canto exótico de pássaros (2010, p. 187); } \\
\text { Suspiro (2010, p. 187); Canto de paissaro suspirante (2010, p. 189); } \\
\text { Scherzo infantil (2010, p. 189); Música indigena (2010, p. 189); Estilo } \\
\text { culto de música composta (2010, p. 189). }\end{array}$ \\
\hline Gabriel Moreira & Tópicas indigenas; tópica do natural; tópica do primitivo, \\
\hline Marcelo Cazarré & $\begin{array}{l}\text { Africanas: Batucando; Canto responsorial; Chamadas; Acentos; Melodia } \\
\text { folk; Ostinato; Possessũo; Sincopação; Alteração discursiva; } \\
\text { Virtuosidade; A La Havana. }\end{array}$ \\
\hline Diósnio Neto & $\begin{array}{l}\text { Tópicas no periodo colonial brasileiro; Tópica marcha fúnebre, Tópica } \\
\text { estilo eclesiástico. }\end{array}$ \\
\hline $\begin{array}{l}\text { Danicl Zanella dos } \\
\text { Santos }\end{array}$ & $\begin{array}{l}\text { Tambores indigenas; Murmúrios da floresta noturna; Canto de páissaro; } \\
\text { Perseguição; Dança primitiva. }\end{array}$ \\
\hline
\end{tabular}

Fig. 2- Alguns autores brasileiros e tópicas musicais

Para o presente artigo, analisarei primeiramente a ocorrência da tópica canto de xangô em algumas obras de Heitor Villa-Lobos. Para considerar canto de xangô como uma tópica, é necessário verificar sua ocorrência, convenção e utilizações, a fim de que seja reconhecida como um senso comum dentro de um contexto cultural, utilizada em diferentes obras, e uma figura de representação amplamente utilizada e comumente aceita (mesmo pondendo ser móvel de acordo com o idiomático de cada compositor). Verificaremos ao final deste trabalho que, além de presente na obra de Villa-Lobos, a tópica canto de xangô pode ser verificada em outras obras do repertório brasileiro que também sofreram reflexos e influências afro-brasileiras, tanto dentro do repertório da música erudita quanto da música popular. Assim, ao tratarmos da música brasileira, segundo Piedade, é possível

aplicar a teoria das tópicas nesta comunidade cultural e historicamente situada que se entende enquanto uma nação, mesmo recortada por diversos e divergentes estilos internos. [...] Note-se que as tópicas flutuam acima da fronteira popular-erudito, e deste modo [é possível tratar] da musicalidade brasileira sem me ater a esta distinção (PIEDADE, 2013, p.7). 


\section{O tipo xangô e a tópica canto de xangô}

Eero Tarasti, musicólogo e semiólogo finlandês, é autor de um livro sobre Villa-Lobos (Heitor Villa-Lobos - the life and Works, 1887 - 1959). Nele, Tarasti usa o termo "Xangô-type themes" para designar trechos dos Quartetos de cordas n. 4 e n. 6 de Villa-Lobos que seguem um padrão de temas de tipo xangô. Como dito acima, um pouco depois, Tarasti explica que a combinação de um tema de tipo xangô contra um acompanhamento sincopado (contramétrico ${ }^{8}$ ) de subdivisão quaternária é uma das mais comuns tópicas encontradas em Villa-Lobos. (TARASTI, 1995, p. 308). Nas análises feitas por Tarasti, veremos que este acompanhamento contramétrico vem normalmente em caráter de ostinato. Esta combinação tema de tipo xangô (normalmente em valores mais longos, em tom de evocação e reverência) contra um ostinato de ritmo mais condensado que a melodia, é o que chamaremos aqui de tópica canto de xangô.

Segundo Hatten, o tipo é "uma categoria ideal ou conceitual definida por características ou uma série de qualidades que são essenciais para a sua identidade" (HATTEN, 1994, p. 44). Dentro dos estilos afro-brasileiros em geral podemos observar alguns ti-

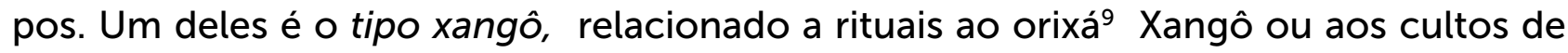
xangô. Prandi e Vallado (2010, s.p.) narram que :

Segundo a mitologia, Xangô teria sido o quarto rei da cidade de Oió, que foi o mais poderoso dos impérios iorubás. Depois de sua morte, Xangô foi divinizado, como era comum acontecer com os grandes reis e heróis daquele tempo e lugar, e seu culto passou a ser o mais importante da sua cidade, a ponto de o rei de Oió, a partir daí, ser o seu primeiro sacerdote. Não existem registros históricos da vida de Xangô na Terra, pois os povos africanos tradicionais não conheciam a escrita, mas o conhecimento do passado pode ser buscado nos mitos, transmitidos oralmente de geração a geração. Assim, a mitologia nos conta a história de Xangô, que começa com o surgimento dos povos iorubás e sua primeira capital, Ilê-Ifé, fala da fundação de Oió e narra os momentos cruciais da vida de Xangô.

Além disso, Câmara Cascudo $(2012$, p. 731) descreve no Dicionário do Folclore Brasileiro que Xangô é "um dos mais populares, prestigiosos e divulgados orixás dos candomblés, terreiros, macumbas, do Recife ao Rio Grande do Sul. [...]. Foi trazido pelos escravos vindos de Togo, Daomé, Lagos, barra do Níger, golfo do Benin, jejes e iorubás ou nagôs". Tudo isso mostra um pouco da importância do orixá Xangô dentro da cultu-

\footnotetext{
8 A palavra contrametricidade (ou ritmo contramétrico) será adotada, neste artigo, no lugar da palavra síncope, de acordo com as definições propostas por Sandroni (2001). Segundo o autor, a definição de sincope como um efeito de ruptura no discurso musical quando a regularidade da acentuação é quebrada "indica [...] uma ocorrência percebida como desvio na ordem normal do discurso musical" (SANDRONI, 2001, p. 19). Ele ainda explica que a palavra sincope foi um conceito criado por teóricos da música erudita ocidental. Entendemos, portanto, que não é tão adequado adotar essa palavra na música brasileira, pois a síncope não é algo anormal, mas faz parte de algo que é comum, usual e normal a essa cultura. Em outras palavras, a anornmalidade europeia é aqui a normalidade brasileira, e contrametricidade torna-se um recurso normal e não uma exceção. Sandroni também explica que a síncope e sua recorrência é carregada de semântica, pois é "associada com 'Brasil', com 'negro' e com 'popular'" (SANDRONI, 2001, p. 47).
}

Segundo Carvalho, "os orixás funcionam basicamente como intermediários entre um deus abstrato (hoje em dia praticamente assimilado ao Deus católico) e os homens. São chamados de "santos" justamente por jogarem esse papel mediador, a partir do qual se estabeleceu o fenômeno do sincretismo, ou equivalência significativa entre as divindades africanas e alguns santos católicos mais cultuados no país" (CARVALHO, 1991, p. 2-3). Segundo Câmara Cascudo (2012, p. 506), os orixás são "divindades da religião iorubana, intermediárias entre os devotos e a suprema divindade, inacessível às súplicas humanas. Simbolizam forças naturais [...]". 
ra brasileira. Em Pernambuco, Xangô acabou por dar nome a toda a religião dos orixás, que em praticamente todos os outros estados do Nordeste é conhecida como xangô. Carvalho (1991, p. 2) explica que "o culto xangô de Recife pertence ao padrão religioso afro-brasileiro tradicional, sendo um equivalente, guardadas as diferenças, do candomblé baiano". Priscila Paes descreve que

pouco a pouco a música e dança negra foram se expandindo pelas várias regiõess do país, influenciando e sofrendo influências, surgindo o que chamamos de música afro-brasileira. A música negra penetrou no mundo dos brancos a partir da presença de serviçais ${ }^{11}$ negros em suas casas. Com o acordar para os valores nacionais, a música erudita partiu à procura das raízes brasileiras. Nessa busca, entre os vários elementos encontrados, um deles foi o afro-brasileirismo. Folcloristas coletaram cantigas de trabalho, de terreiro, de ninar, levantando-se vasto material sobre a música dos negros no Brasil (PAES, 1989, p.66).

Entendemos, portanto, que tudo que de alguma forma simbolize características de rituais ao orixá Xangô, ou o culto de xangô (como ritmos, melodias, instrumentos, danças, etc.), ou o próprio mito de Xangô, pode ser considerado como tipo xangô. Dentro do tipo xangô, podemos localizar a tópica canto de xangô, que tem uma distribuição textural específica que será explicada e analisada mais adiante. A partir desta análise, e da pesquisa de outros autores sobre materiais e elementos afro-brasileiros, podemos reunir algumas características principais e musicais do tipo xangô e da tópica canto de xangô. São elas:

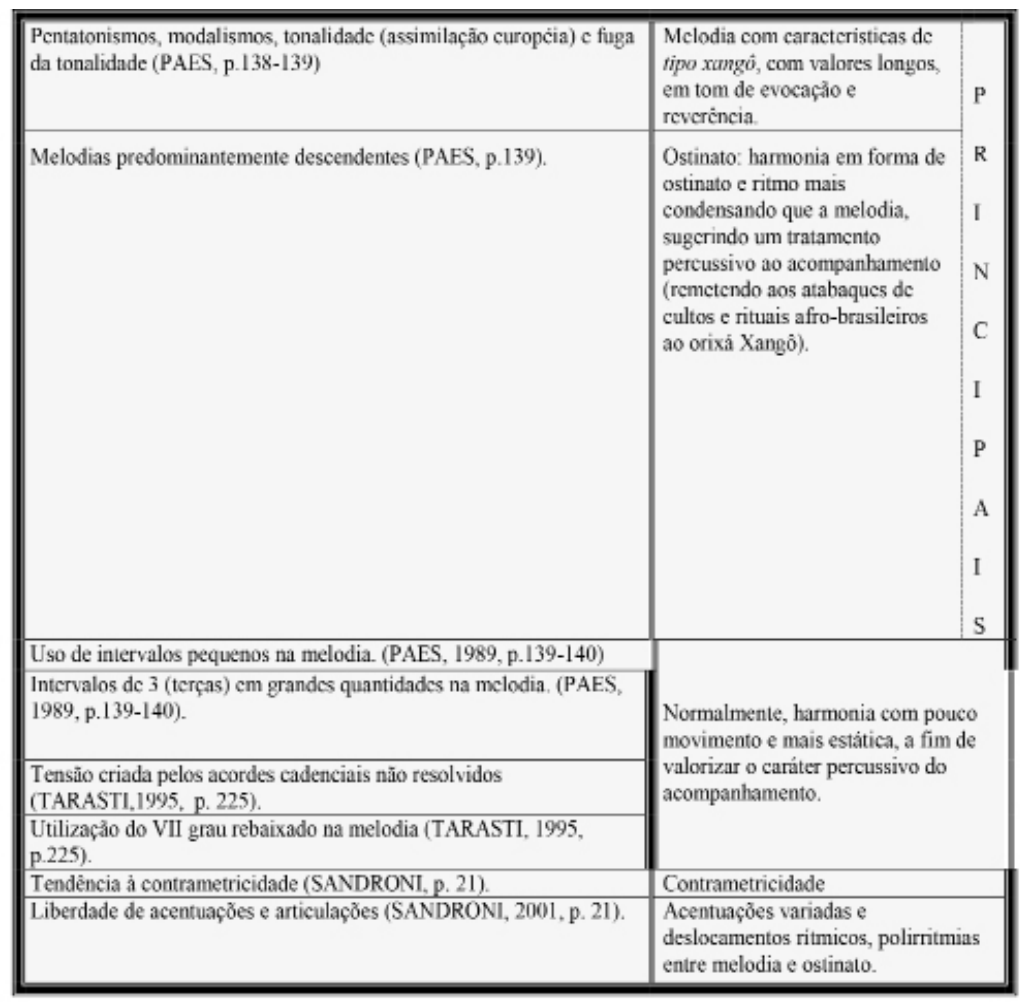

Fig. 3- Tipo xangô e tópica

\footnotetext{
10 Por este motivo, quando falamos dos cultos afro-brasileiros de uma maneira geral, trataremos xangô com letra minúscula, e quando falarmos diretamente sobre o orixá, trataremos com letra maiúscula (Xangô).

11 De acordo com o dicionário Michaelis (1998-2009), um serviçal pode ser um criado ou criada de servir, uma pessoa assalariada ou servente. Deste ponto de vista, fica questionável a escolha de Priscila Paes $(1989$, p. 66) por utilizar a palavra serviçal, já que muitos destes negros que trabalhavam nas casas de brancos ainda eram escravos. A palavra escravo, apesar de também poder ser sinônimo de serviçal no sentido de ser um criado ou criada de servir, pode ser definida, diferentemente, como o que vive em absoluta sujeição a um senhor, não sendo uma pessoa assalariada (como um serviçal por vezes pode ser).
} 
Podemos considerar, portanto, que as principais características da tópica canto de xangô são:

- Melodia com algumas características do tipo xangô, com durações mais longas que o acompanhamento (contraste rítmico), representando um caráter de evocação e reverência às divindades dos cultos e rituais afro-brasileiros.

- Ostinato: harmonia em forma de ostinato (normalmente com pouco movimento e mais estática), sugerindo um tratamento percussivo ao acompanhamento, que possui um ritmo mais condensado que a melodia. Ainda é possível encontrar polirritimias entre a melodia e o ostinato, bem como contrametricidade, acentuações variadas e deslocamentos rítmicos.

As características do quadro acima (que, em sua maioria, também podem ser características do estilo afro-brasileiro em geral) podem ser encontradas também em outras tópicas afro-brasileiras, já que as características de um estilo, tipo ou tópica podem ser móveis, e reinterpretadas em diferentes contextos. Porém suas combinações, e/ou o contexto em que são utilizadas é que definem os significados que adquirem. Portanto, em síntese, podemos reforçar que a característica mais forte e marcante da tópica canto de xangô é uma melodia em valores mais longos que o acompanhamento, em tom de evocação e reverência, típica dos rituais, contraposta a um acompanhamento (normalmente em forma de ostinato) de ritmo mais condensado, como representação percussiva dos atabaques dos cultos e rituais afro-brasileiros.

\section{Possíveis representações, significados e simbologias da tópica canto de xangô}

Ao usar temas e trechos com características de tipo xangô, os compositores trazem uma carga intuitiva de representação de um senso comum e de uma convenção ou memória cultural. Várias representações e simbologias são possíveis ao falarmos da tópica canto de xangô. Por exemplo, o ostinato presente na tópica canto de xangô (e levando em consideração que a tópica é um ato simbólico de representação) traz uma textura percussiva que pode remeter aos atabaques e percussões de rituais ou cultos afro-brasileiros, e sua respectiva repetição também pode aludir ao transe característico destes rituais.

Outra abordagem que utilizei neste trabalho foi encontrar simbologias e analogias da tópica canto de xangô com o mito de Xangô. Isto pode ser possível por três motivos principais:

1) Pela importância do mito dentro da cultura africana e da cultura afro-brasileira. Adolfo nos diz que: "as ações das divindades são relatos que reconstroem os fatos e dão sentido à vida do homem religioso, sendo que sem mito não há religião, pois o mito é a palavra e a poesia é sempre tributária da palavra" (ADOLFO, 2008, p. 211).

2) Porque, assim como a tópica, o mito também tem um caráter simbólico de 
representação. As religiões afro-brasileiras cultuam deuses míticos, e por isso torna-se quase impossível e inviável distanciar o mito de uma análise de significação e simbologias do discurso e da estrutura musical, principalmente em se tratando de obras com influência afro-brasileira. Por exemplo, Lévi-Strauss explica os mitos de uma perspectiva estruturalista, analisando-os de maneira a relacioná-los a uma forma musical como ária, recitativo, variações, suíte, dentre outras (LEVI-STRAUSS, 1991). Da mesma forma, podemos expandir este processo, complementando-o ao comparar e incorporar os mitos dentro do discurso musical como uma forma de significação e representação de elementos da estrutura musical. Levi-Strauss ainda descreve que:

Deve ser possível descobrir no discurso musical uma função especial que apresente uma afinidade especial com o mito, e que virá, digamos, inscrever-se como expoente da afinidade geral, já constatada entre o gênero mítico e o gênero musical quando considerados como um todo. (LEVI-STRAUSS, 1991, p.36)

3) Possivelmente Villa-Lobos teve contato com mitos. Isto pode ser observado na segunda edição do catálogo de obras de Villa onde vê-se que o compositor teve contato com livros como Poranduba Amazonense (de João Barbosa Rodrigues, 1890).

Assim, se levarmos em consideração o mito de Xangô, podemos ir mais longe na representação simbólica dentro da música, e perceberemos que o ostinato pode representar também o fogo (a que o povo chamava de raio) que o rei Xangô atirava sobre sua cidade Oió. Segundo o mito, o que o povo chamava de raios, eram os jatos de fogo que Xangô cuspia sobre a nação, e os trovões eram as explosões que aqueles jatos de fogo causavam. Com isso, Xangô colocou fogo em sua própria cidade. O ostinato pode, portanto, ser uma representação do barulho de raios caindo continua e incessantemente sobre a terra, como diz o mito (PRANDI; VALLADO, 2010, s.p.). Devemos lembrar também que Xangô é considerado o orixá da justiça. Num mundo de tantas injustiças [...] "o orixá da justiça ganhou cada vez maior importância. Seu prestígio foi consolidado. Reiterou-se a posição de Xangô como o grande patrono do candomblé e grande protetor de todo aquele que se sente de algum modo injustiçado" (PRANDI; VALLADO, 2010, s.p.).

Levando em consideração o conceito de Tarasti sobre um tema de tipo xangô contra um acompanhamento contramétrico de subdivisão quaternária ser uma das mais comuns tópicas encontradas em Villa-Lobos (TARASTI, 1995, p. 308), e percebendo como este acompanhamento é normalmente em perfil de ostinato, chamaremos esta tópica de canto de xangô (por ter a melodia do Canto de Xangô, que demonstraremos adiante, como parte formadora desta e a canção Xangô de Villa-Lobos como representação sonora desta tópica). Demonstraremos abaixo as manifestações e utilizações desta tópica em algumas obras de Villa-Lobos, bem como de outros compositores brasileiros. 


\section{A tópica canto de xangô em Villa-Lobos}

A canção Xangô, de Villa-Lobos, é um canto de fetiche de macumba, e faz parte do ciclo Canções típicas brasileiras do compositor (MUSEU VILLA-LOBOS, 2010, p. 186). Este ciclo de canções foi composto no Rio de Janeiro e dedicado à cantora Elsie Houston. Segundo Nahim Marun, "essa foi uma das primeiras manifestações do compositor em direção a uma liberação da arte pelo folclore ${ }^{12 " ~(M A R U N, ~ 2010, ~ p .35) . ~ A ~ c a n c ̧ a ̃ o ~}$ Xangô foi composta no ano de 1919, e Villa-Lobos disponibilizou 3 versões desta obra (sendo que a versão orquestrada possui 2 versões diferentes), totalizando 4 versões:

1- $\quad$ Canto e piano (1919)

2- Versão orquestrada (1919): a) 2 fagotes, 2 corne-inglês, timpano, bateria (bumbo, surdo e tam-tam), harpa, piano, canto e cordas; b) corne-inglês, fagote, cor, trompete, trombone, timpano, bateria, piano ou harpa, canto e cordas

\section{3- $\quad$ Coro a 5 vozes (1935)}

Tarasti explica que esta canção é a harmonização de uma melodia citada por Oneyda Alvarenga em Música Popular Brasileira. Antes das referências ao Canto de Xangô feitas por Tarasti e Oneyda Alvarenga, porém, esta melodia já havia sido registrada e citada por Mário de Andrade e posteriormente por Arnaldo Estrella. Partindo disto, temos a cronologia de referências ao Canto de Xangô:

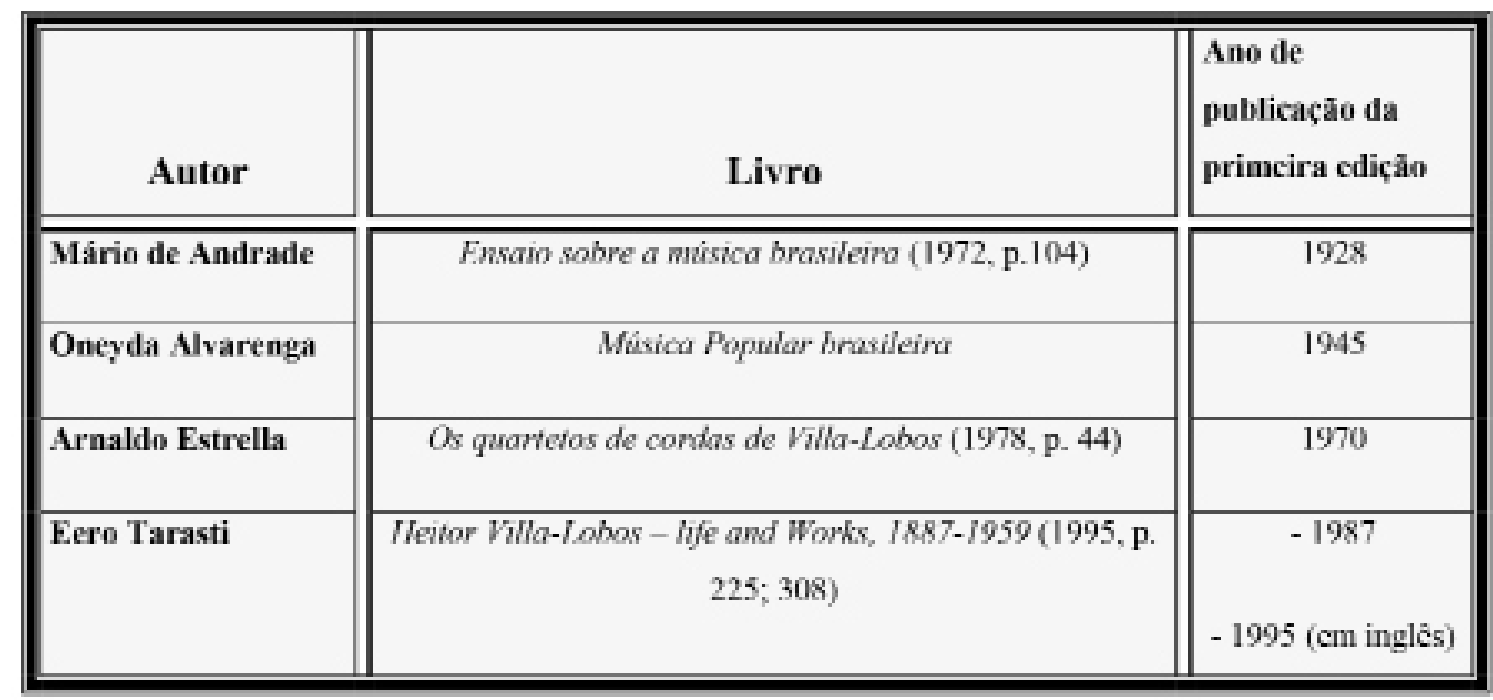

Fig. 4- Cronologia de referências ao Canto de Xangô

Abaixo podemos ver a melodia do Canto de Xangô recolhido por Mário de Andrade e registrado em seu livro Ensaio sobre a música brasileira (1972, p. 104):

\footnotetext{
12 Como dito no começo deste artigo, Priscila Paes explica que "a música negra penetrou no mundo dos brancos a partir da presença de serviçais negros em suas casas. Com o acordar para os valores nacionais, a música erudita partiu à procura das raízes brasileiras. Nessa busca, entre os vários elementos encontrados, um deles foi o afro-brasileirismo. Folcloristas coletaram cantigas de trabalho, de terreiro, de ninar, levantando-se vasto material sobre a música dos negros no Brasil." (PAES, 1989, p.66).
} 


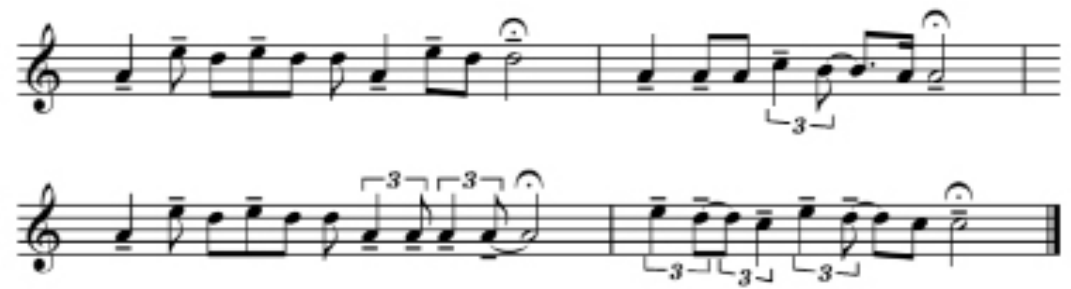

Fig. 5- Canto de Xangô recolhido por Mário de Andrade

Segundo Tarasti, em Xangô, Villa-Lobos trabalha com a "melodia em valores de tempo longos como uma espécie de contrabalanço polirritimico ao motivo quadrangular do acompanhamento em que o piano é tratado percussivamente" (TARASTI, 1995, p. 225, tradução desta autora). Essa combinação, segundo o autor, seria um tipo de arquétipo da qualidade de afro-brasileiro. Segue abaixo trecho da canção de Villa-Lobos na versão para canto e piano onde podemos perceber a melodia ritmicamente aumentada em relação ao Canto de Xangô recolhido por Mário de Andrade. Podemos observar isso logo no começo da canção:
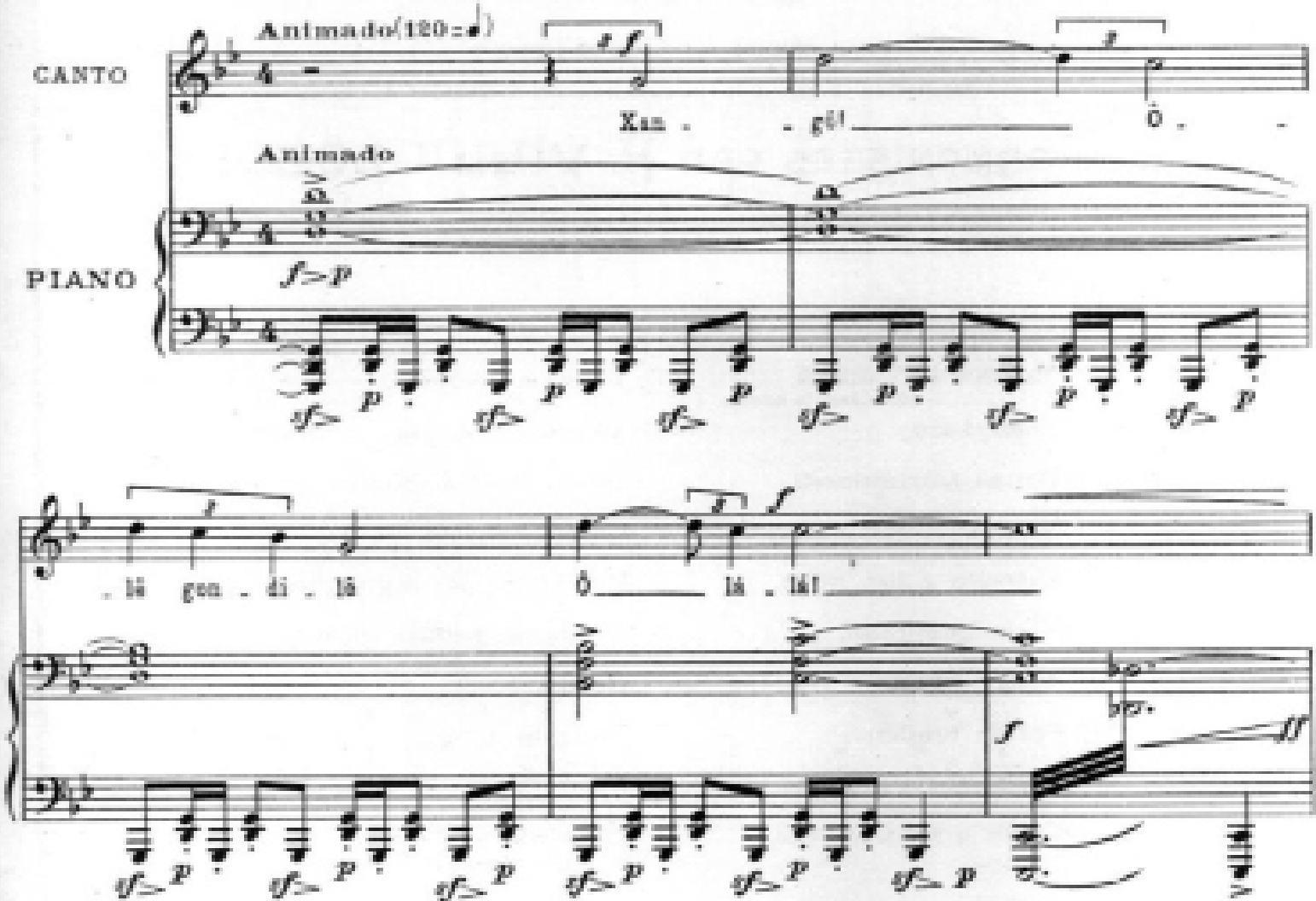

Fig. 6 - Canto de Xangô - versão de Villa-Lobos para canto e piano (c. 1-5) 
Este trecho nos mostra o tema de tipo xangô (com características como polirritimias, notas longas, contornos melódicos descendentes, etc.) na voz, contrastando com um acompanhamento de subdivisão quartenária na mão esquerda do piano. Esse acompanhamento percussivo relatado por Tarasti é executado em forma de ostinato, completando a representação da tópica canto de xangô. Nesta canção, o acompanhamento é modificado apenas quando um "trêmolo e um glissando interrompem o ostinato nos compassos 5, 9, 13 e 17" (MARUN, 2010, p. 48).

Alguns possíveis significados e simbologias da tópica canto de xangô dentro da canção Xangô de Villa-Lobos podem ser:

- Os atabaques de um ritual religioso de um culto afro-brasileiro simbolizados pelo ostinato da mão esquerda, que possui uma harmonia estática que reforça a textura e a qualidade percussiva do acompanhamento do piano.

- O transe característico destes rituais, simbolizado pela repeticão causada pelo ostinato.

- Representação do mito de Xangô: o ostinato pode ser também uma representação do barulho de raios caindo incessantemente sobre a terra, como diz o mito (PRANDI; VALLADO, 2010, s.p.). Xangô é normalmente conhecido como deus dos raios, do trovão e do fogo, em razão do mito.

Estas analogias podem ser aplicadas nas outras obras onde é encontrada a tópica canto de xangô. Essa canção de Villa-Lobos ilustra a razão de chamarmos de canto de xangô a tópica identificada por Tarasti, já que ela possui a representação sonora desta tópica, com a melodia do Canto de Xangô (recolhida por Mário de Andrade) contra um ostinato com uma harmonia estática, que traz um caráter percussivo ao acompanhamento.

Tarasti nos trás alguns exemplos da utilização dessa tópica em outras obras de Villa-Lobos. Um dos exemplos dados por ele é o Quarteto de cordas n.4 (TARASTI, 1995, p. 304). Abaixo podemos ver os compassos 1 a 8 do II movimento, onde o cello realiza o tema de tipo xangô e os outros instrumentos realizam um ostinato que fornece um caráter percussivo ao acompanhamento, fazendo com que esse conjunto de caracteristicas gere a tópica canto de xangô:
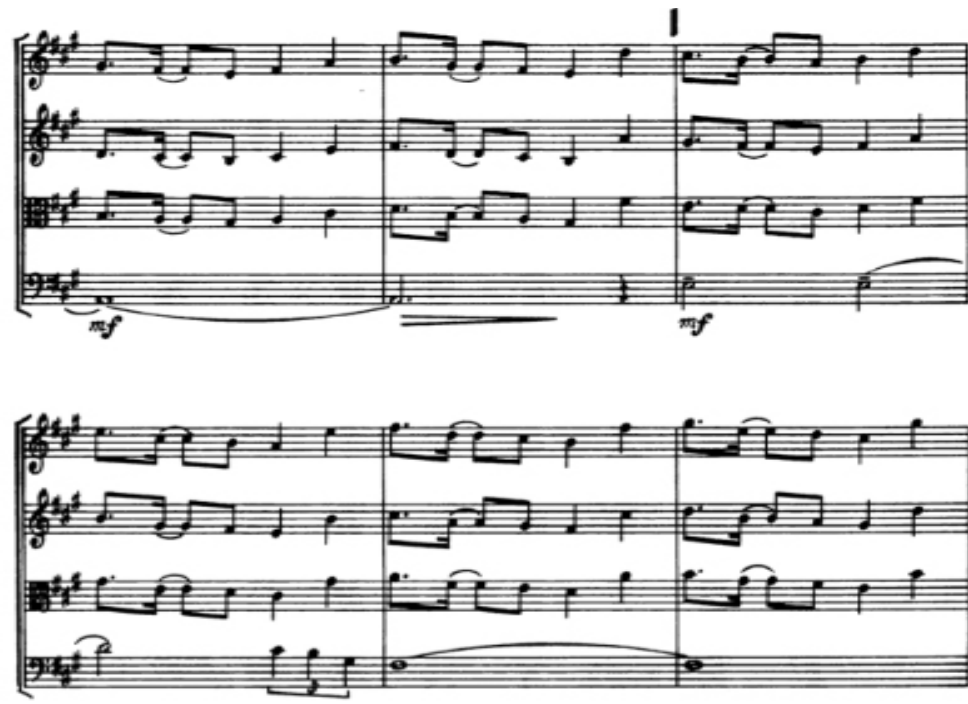

Fig. 7 - Quarteto de Cordas n.4 - tópica canto de xangô (II, c. 1-8) 
Tarasti também exemplifica o Quarteto de cordas n. 6, onde temos um tema de tipo xangô no cello contra um ostinato executado pelos outros instrumentos. Portanto, melodia de tipo xangô do cello + ostinato = tópica canto de xangô. Segue abaixo exemplo do I movimento, compassos 117 a 122:

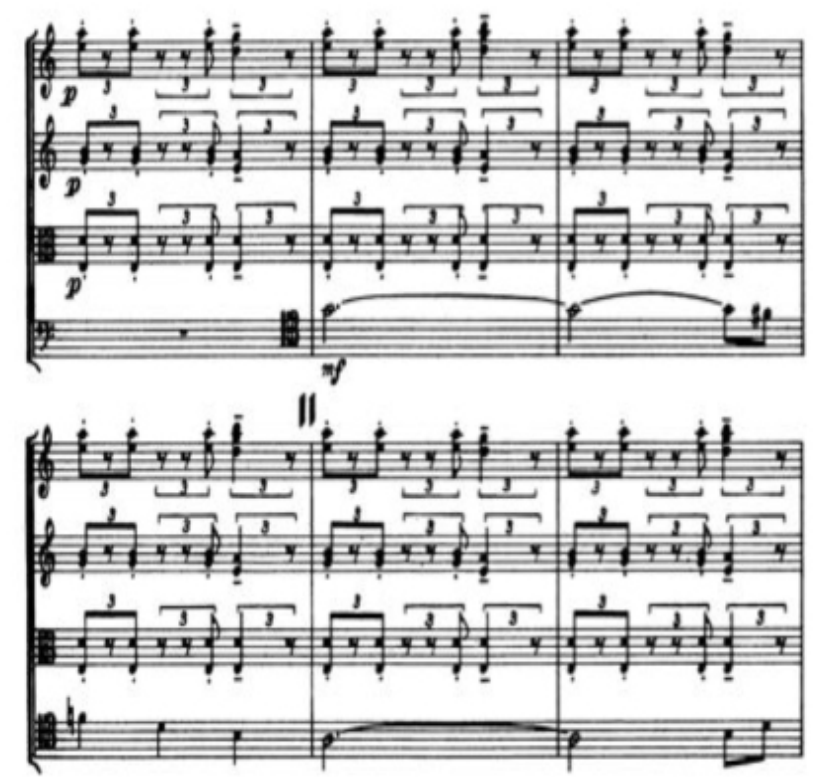

Fig. 8 - Quarteto de Cordas n.6 - tópica canto de xangô (I, c. 117-122)

Ainda no Quarteto n. 6, mas agora no II movimento, podemos ver nos compassos de 6 a 11 a presença de ostinato + melodia de tipo xangô (com valores mais longos que o ostinato). De novo, a melodia de tipo xangô + ostinato = tópica canto de xangô. Além disso há a presença de polirritmia e contrametricidade.
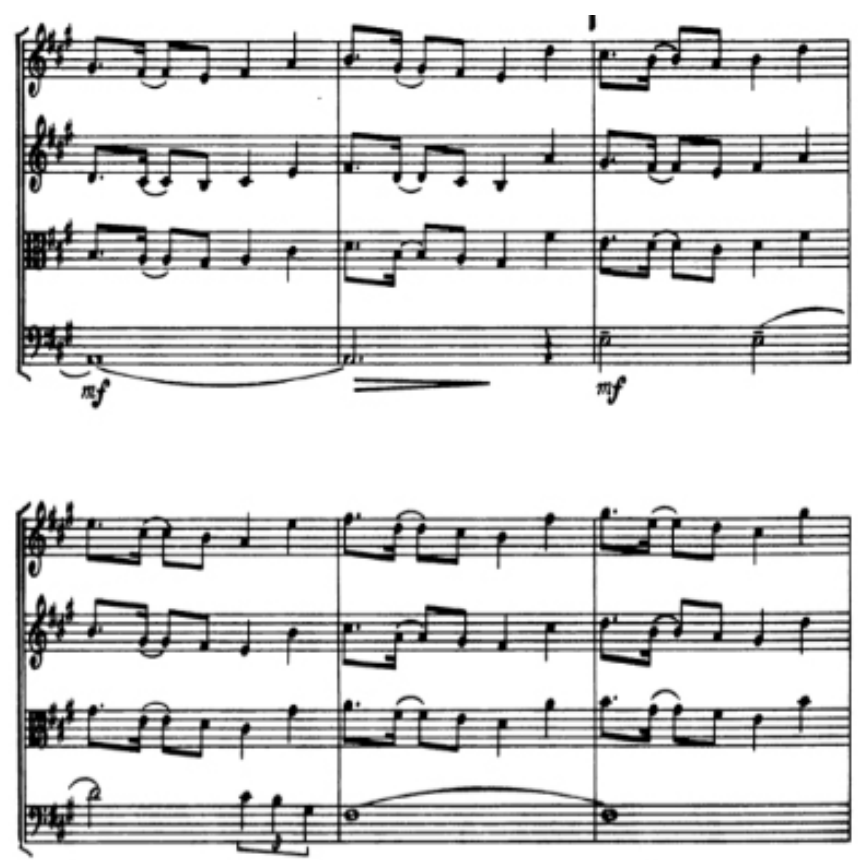

Fig. 9 - Quarteto de Cordas n.6 - tópica canto de xangô (II movimento, c. 6-11) 
Após esses exemplos localizados por Tarasti, podemos localizar também o tipo xangô e a tópica canto de xangô em outras obras. Um exemplo desta utilização está nas Danças características africanas, na peça Kankukus, em que uma melodia em valores mais longos e contornos melódicos descendentes é colocada em contraposição com um ostinato, gerando a tópica canto de xangô:

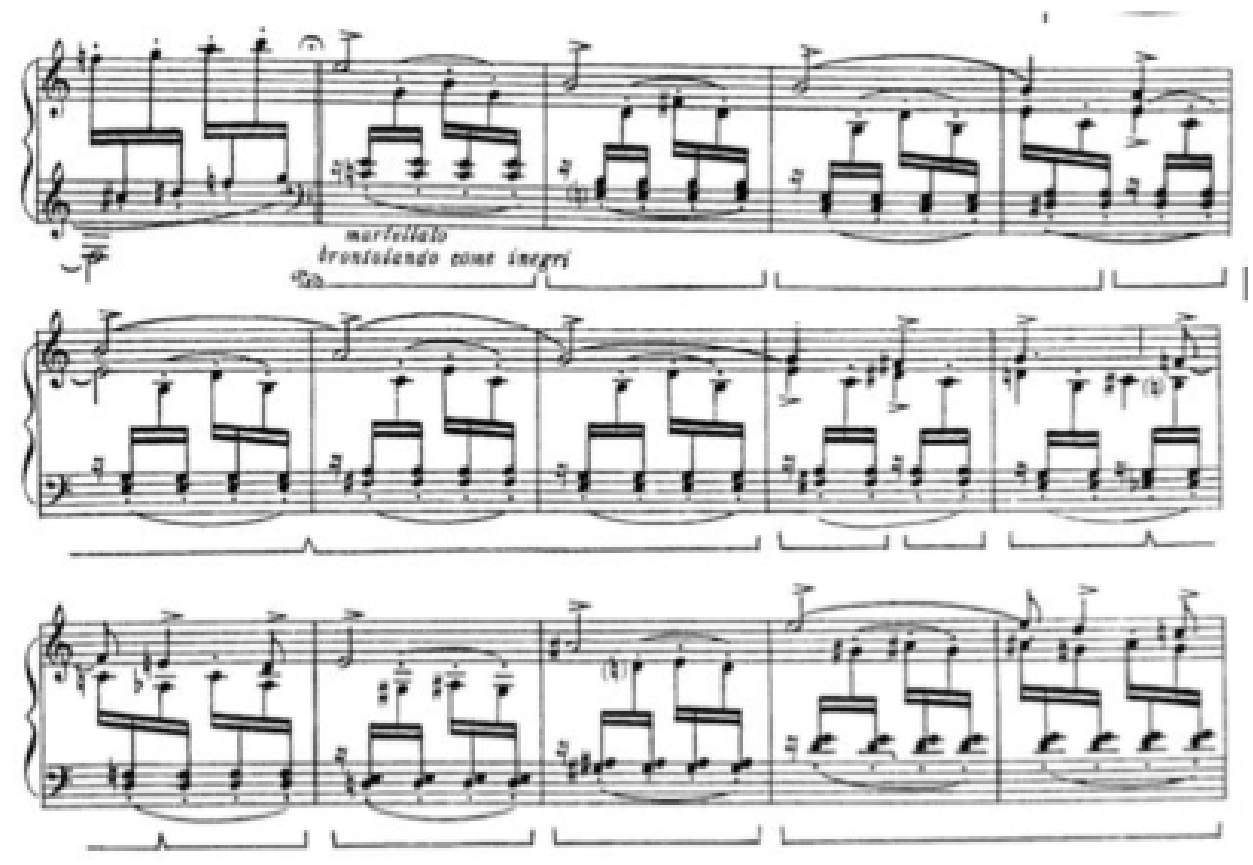

Fig. 10- Tópica canto de xangô na peça Kankukus, das Danças Características Africanas (c. 94 a 108)

\section{A tópica canto de xangô em outros compositores brasileiros}

Outros compositores brasileiros como Camargo Guarnieri, Moacir Santos e Baden Powell fizeram uso de temas do tipo xangô e da tópica canto de xangô em seu repertório, como veremos abaixo.

Dança Negra é uma peça para piano composta por Camargo Guarnieri em 1946. Em 1947, o compositor produziu um arranjo desta peça para orquestra e no ano seguinte transcreveu-a para dois pianos. Em um vídeo ${ }^{13}$ gravado antes de um recital feito por Eudóxia de Barros, a pianista brasileira relata que Camargo Guarnieri a escreveu depois de uma visita que fez a uma sessão de candomblé na Bahia, e que esta obra foi resultado de uma impressão que Guarnieri teve no caminho de ida e volta do terreiro, quando ouvia continuamente um mesmo ritmo contramétrico. Quando se aproximava do terreiro, o som ficava cada vez mais forte, e o contrário na volta, à medida que ia se distanciando. Naquela mesma noite, ao chegar ao hotel, Camargo Guarnieri escreveu 
a peça. Dança Negra faz parte de uma triologia de três danças: Dança Selvagem, Dança Negra e Dança Brasileira.

A mão esquerda do piano utiliza, durante parte predominante da peça, um ostinato que sugere um caráter percussivo a este acompanhamento, possivelmente remetendo e simbolizando também as percussões de rituais de cultos afro-brasileiros. Esse ostinato presente na primeira grande sessão da peça (compassos 1 a 28) é construído predominantemente sobre a escala pentatônica maior de do\#. Veremos abaixo um exemplo dessa utilização nos três primeiros compassos da peça:

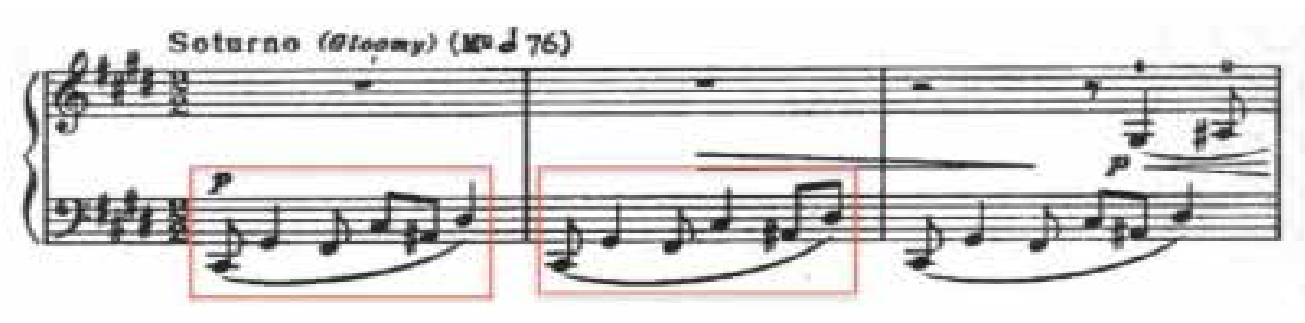

Fig. 11- Dança Negra- pentatônica maior no ostinato da mão esquerda (c. 1-3)

Além disso, essa constância do ostinato pode simbolizar também o caráter de transe característico dos um ritual afro-brasileiro. Freire descreve que:

Na mão esquerda verifica-se que o compositor inseriu um ostinato. A melodia também é bem uniforme. Como a obra foi composta após a visita do compositor a um cerimonial afro, acredita-se que este recurso tenha sido utilizado a fim de "relatar" o procedimento necessário para a chegada dos seus partícipes em um estágio de possessão hipnótica, que nessas manifestações é dado pela repetição dos gestos, movimentos. (FREIRE, 2007, p. 158-159).

Num cerimonial afro, o estágio de transe é atingido, em geral, pela repetição dos movimentos. Trata-se de um processo continuado que tem de fluir naturalmente, a fim de que a pessoa atinja de forma também natural o transe hipnótico. Não se refere a um procedimento rápido, mas circunstanciado, que num dado momento atingirá o clímax. Portanto, esta peça deve ser executada obedecendo-se a este procedimento de naturalidade, espontaneidade, que prepara o momento da incorporação de elementos transcendentes. (FREIRE, 2007, p.162)

Além, das características citadas acima, podemos ouvir e encontrar nesse trecho algumas outras características e seus possíveis significados e simbologias:

- Harmonia estática + uso de escalas pentatônicas = Ambiente soturno proposto por Guarnieri. 
- Ostinato, trazendo mais uma possível simbologia para a tópica canto de xangô: taciturno, melancólico (soturno), que parece estar envolto em trevas; escuro, sombrio, grave, simbolizando também os rituais que geralmente acontecem à noite e o transe

- Contrametricidade, que define bem a relação entre mão esquerda e direita nesta peça. A contrametricidade traz, neste caso, uma sensação de poliritmia e múltiplas acentuações, que também é característica da tópica canto de xangô. A seguir podemos ver a contrametricidade presente entre mão esquerda e direita nos compassos iniciais da peça:
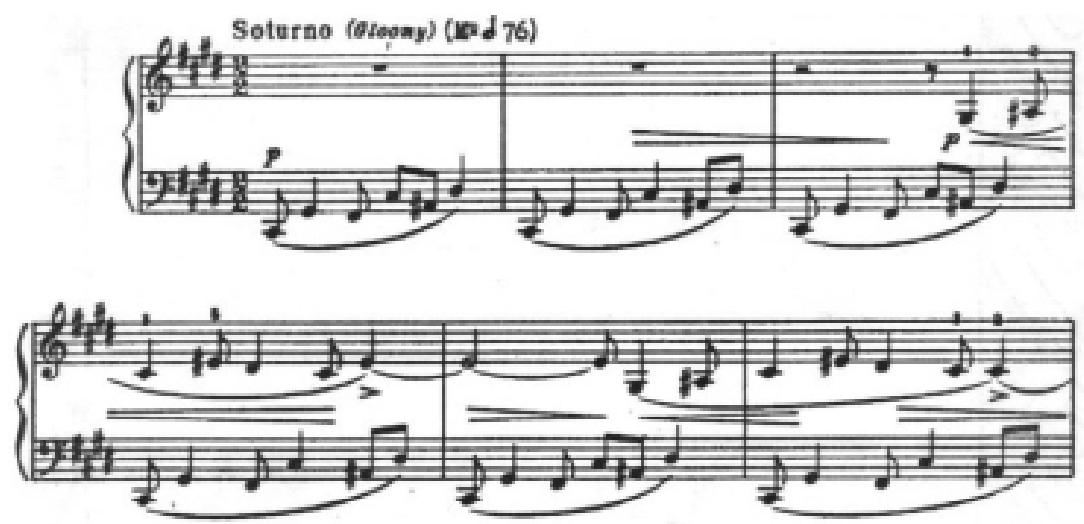

Fig. 12- Dança Negra- contrametricidade entre mão direita e esquerda

Moacir Santos lançou, em 1965, um álbum intitulado Coisas onde está presente a peça Coisa n.5- Nanã. Logo na introdução da peça, como demonstra o trecho abaixo, podemos ver o ostinato feito pelo sax baritono, trombone baixo e contrabaixo, que gera um caráter percussivo. A melodia da introdução surge na flauta, sax alto e sax tenor causando um contraste ritmico com este acompanhamento:

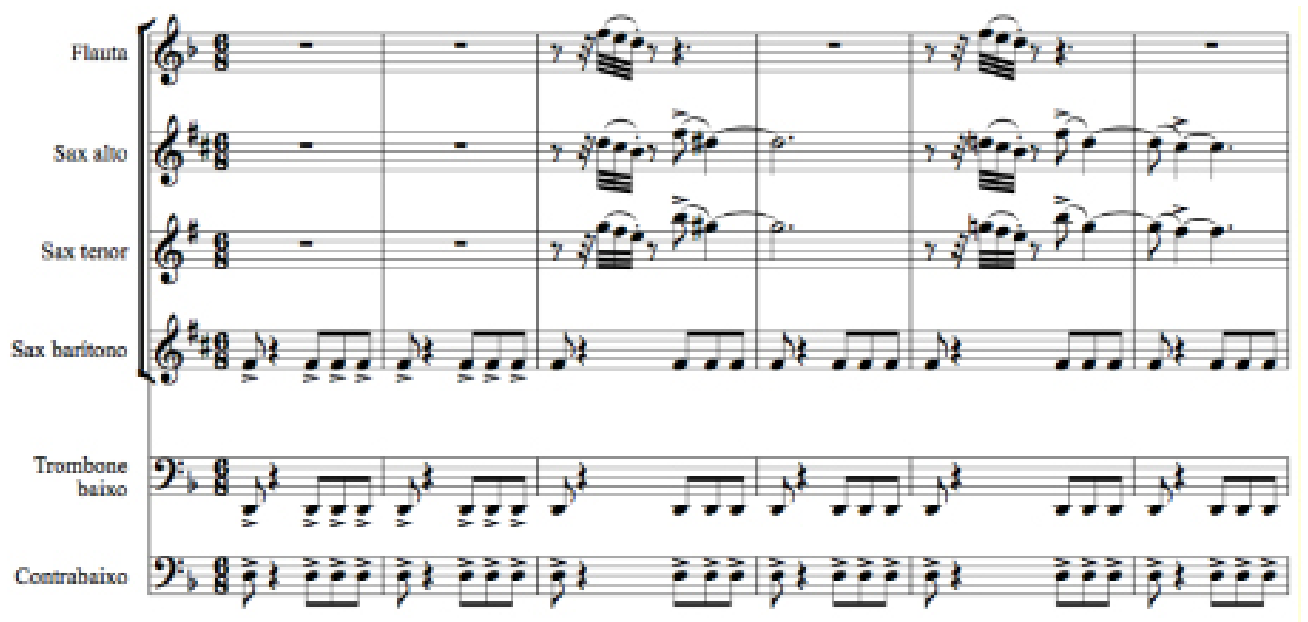

Fig. 13 - Tópica canto de xangô em Nanã, de Moacir Santos (c. 1-6) 14 $^{14}$

14 Transcrição de Zé Nogueira e Mário Adnet (SANTOS, 2005). 
A partir do compasso 22 surge um ostinato feito na guitarra, trompete, sax alto, sax tenor, trompa, e logo depois, no compasso 25 , entra o tema principal da peça feito pelo sax baritono e o trombone. O ostinato é mantido contra a melodia principal, gerando novamente a tópica canto de xangô. É interessante ressaltar ainda que esta melodia é feita por instrumentos graves e em região grave, enquanto os instrumentos que fazem o ostinato são utilizados em região mais aguda que a melodia. Este mesmo procedimento foi usado por Villa-Lobos nos Quartetos de cordas n.4 e n.6 onde também é utilizada a tópica canto de Xangô (como mostrado mais anteriormente):

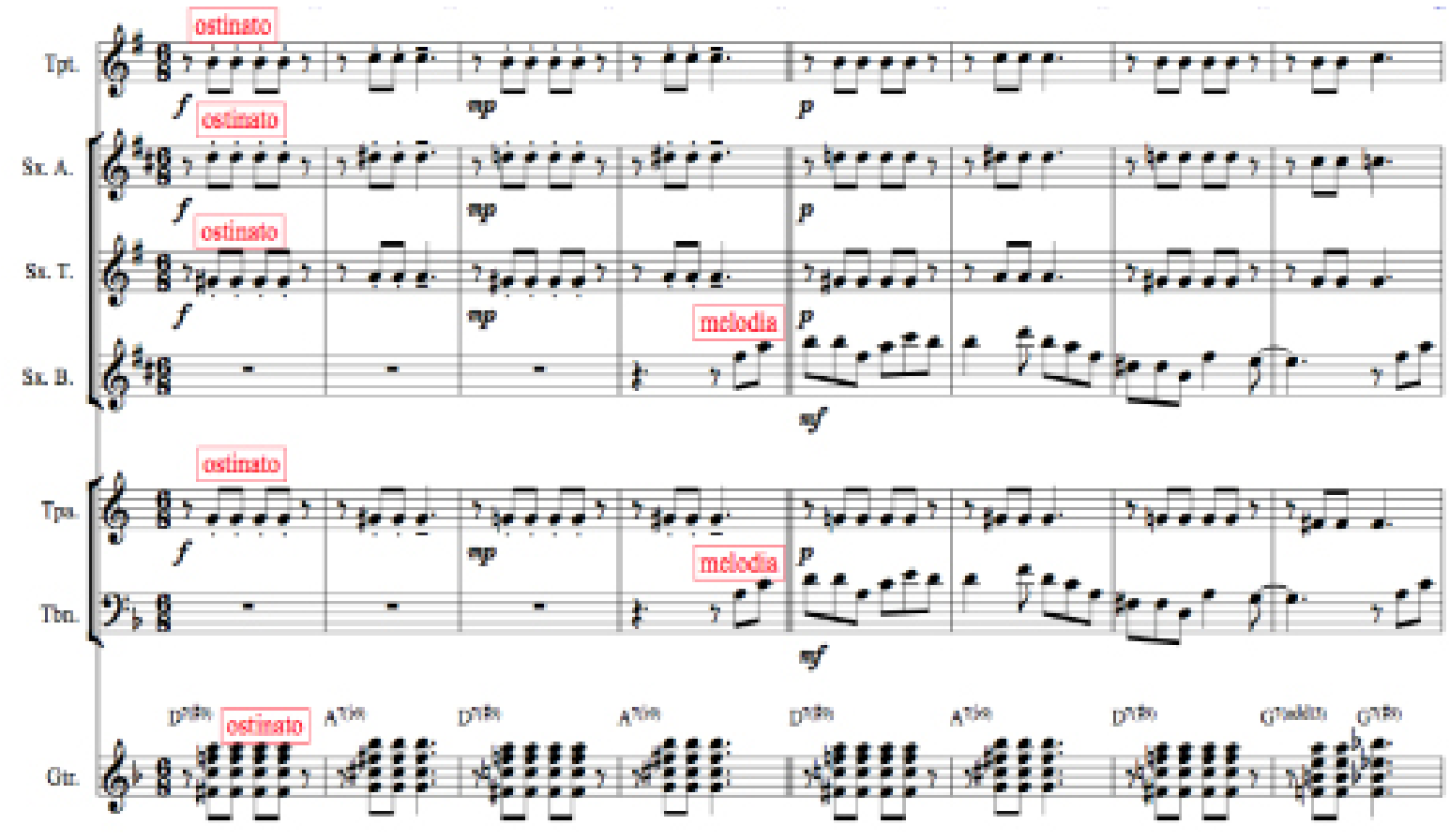

Fig. 14 - Tópica canto de Xangô em Nanã de Moacir Santos (c. 22-29)

Além das características acima citadas, observamos que o ostinato é feito à base de acordes repetidos na guitarra (e as notas desse acorde são distrubuídas aos instrumentos que também realizam o ostinato), reforçando alguns possíveis caracteres simbólicos:

- As percussões e o caráter de transe de cultos ou rituais afro-brasileiros (como por exemplo os cultos de xangô ou candomblé).

- Se levarmos a questão da simbologia e da representação um pouco mais adiante, temos aí também a representação do mito de Xangô, considerando que o tipo de marcação de ostinato e acordes repetidos podem representar o barulho constante e incessante do rei Xangô soltando jatos de fogo em direção à sua cidade de Oió.

- Além disso, as notas longas e fermata da introdução também trazem o tom de evocação e reverência da tópica canto de xangô.

Para finalizar, analisaremos a obra Canto de Xangô, de Baden Powell. Moacir San- 
tos foi professor de Baden Powell e, segundo o Cancioneiro de Moacir,

seria também Baden Powell o primeiro músico a se deixar arrebatar e influenciar pelas "Coisas". Muitos dos famosos afro-sambas que estava compondo na época [...] nasceram justamente nas aulas, como exercícios propostos por Moacir. 0 caráter afro das "Coisas" é responsável por dar a luz aos afro-sambas de Baden e Vinícius de Moraes (SANTOS, 2005, p. 23).

Baden Powell gravou, em 1966, ao lado de Vinicius de Moraes, o álbum Os afro-sambas e, no mesmo ano, o álbum Tristezas on guitar. Dentro de ambos temos a canção Canto de Xangô. Trataremos aqui da transcrição para violão da versão do album Tristezas on guitar. Neste primeiro trecho podemos verificar a presença de um ostinato feito contra uma melodia em valores mais longos e na região grave:

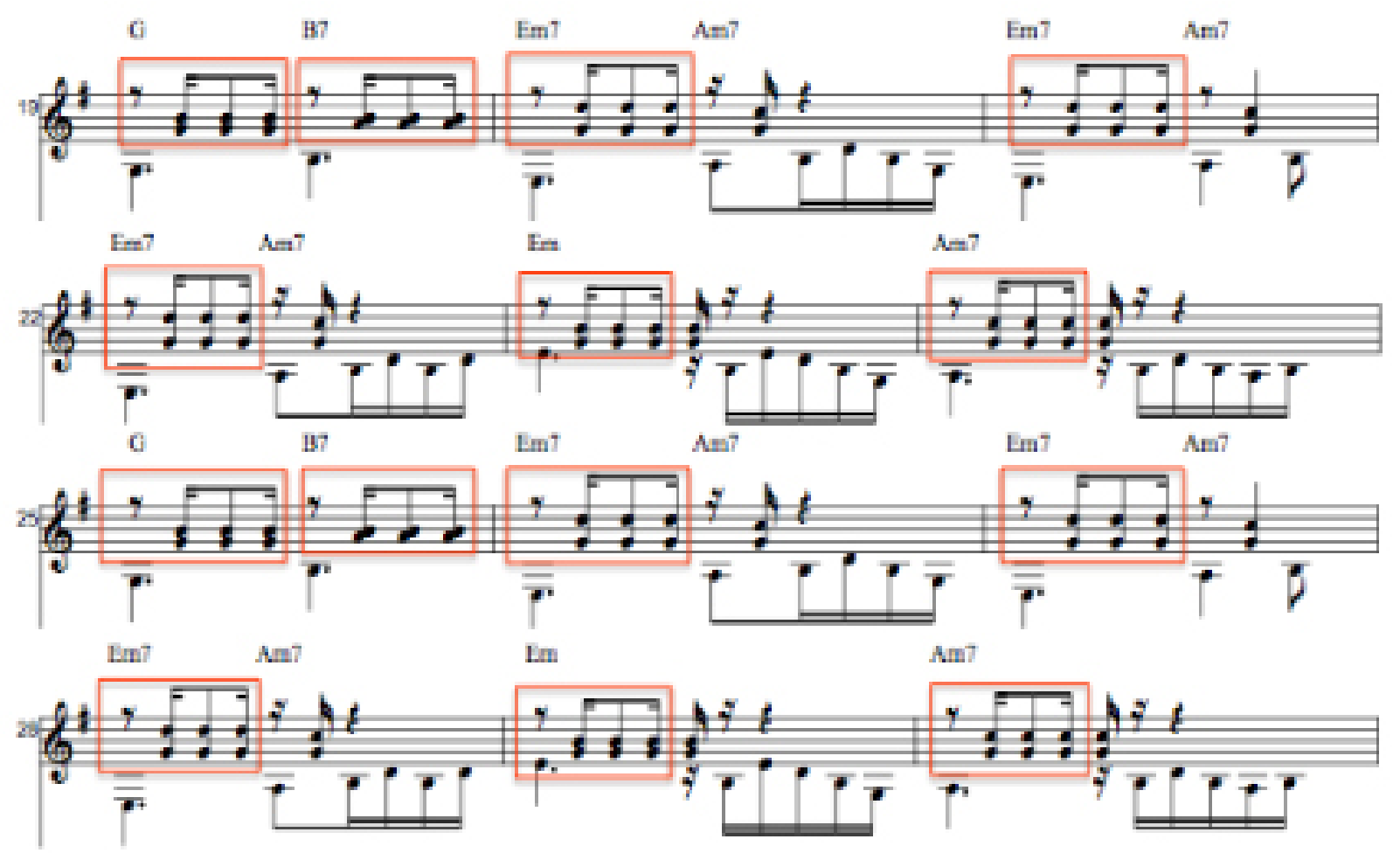

Fig. 15 - Canto de Xangô de Baden Powell (c. 19-30)

Nesse próximo trecho, podemos verificar também um contraste polirritmico entre a melodia que, agora, utiliza ritmos com divisão binária e subdivisão quaternária, e o acompanhamento do violão que utiliza ritmos com subdivisão composta, bem como o VII grau rebaixado na melodia (Ré). Além da poliritmia exemplificada abaixo, entendemos que o violão ganha um carater percussivo ao realizar um acompanhamento contínuo e marcante contra uma melodia com notas de valores mais longos que o acompanhamento. Todas estas caracteristicas são sinalizações da tópica canto de xangô: 


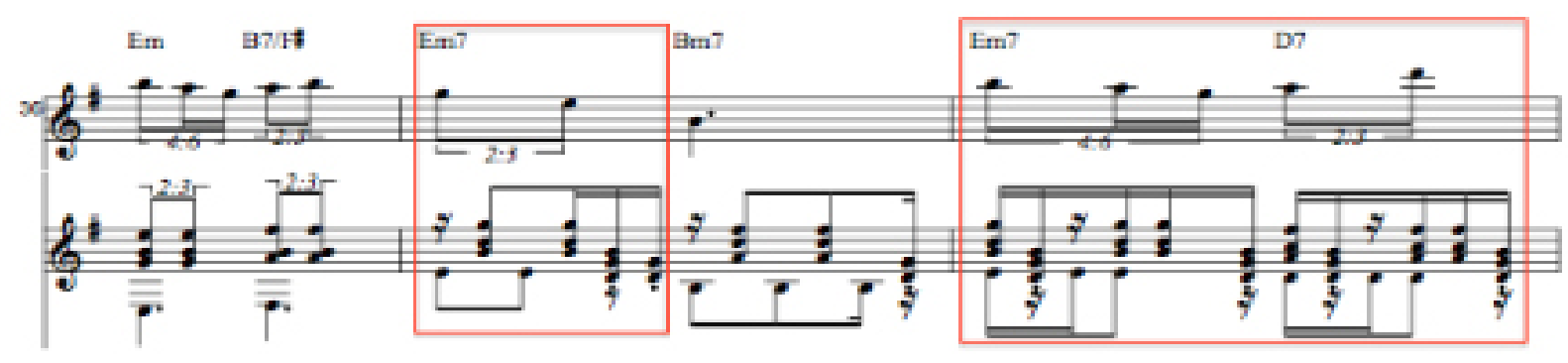

Fig. 16 - Polirritimias entre melodia e acompanhamento contínuo do violão- Canto de Xangô de Baden Powell (c. 36-38)

\section{Conclusão}

A tópica canto de xangô é amplamente utilizada não só na obra de Villa-Lobos, mas também de outros compositores brasileiros como Camargo Guarnieri, Moacir Santos, Baden Powell, dentre outros, e representa parte muito importante da formação da cultura e da música brasileira que é a influência afro-brasileira, bem como os elementos afro-brasileiros. As sinalizações dessa tópica aparecem frequentemente nessas obras como foi mostrado neste trabalho e, por isso, podemos considerar o arquétipo de afro-brasileiro descrito por Tarasti como uma tópica na música brasileira, aqui denominada tópica canto de xangô. Nota-se ainda que a tópica canto de xangô percorre tanto o repertório da música de concerto como a música popular. Isto afirma ainda mais a sua autonomia como uma tópica, por ser encontrada em diferentes obras e contextos. Após estas análises, podemos chegar às seguintes conclusões:

- Podemos ver a utilização do tipo xangô e da tópica canto de xangô como a representação de várias convenções, percepções e impressões dos compositores a respeito dos rituais e cultos afro-brasileiros (ou do orixá Xangô, considerando que Xangô acabou por dar nome a toda a religião dos orixás, ou dos cultos de xangô, ou do candomblé, dentre outros), bem como do mito de Xangô (PRANDI; VALLADO, 2010). Assim, os compositores, através desta tópica, criaram padrões para representar essa característica dos rituais (às vezes de forma generalizada e não específica, mas idealizada e estilizada), que são os atabaques contra uma melodia em tom de evocação e reverência, com uma visão idealizada dessa realidade.

- É desta forma que o tipo xangô e a tópica canto de xangô irão trazer consigo algumas características, memórias, impressões e intenções que definem a maneira como a música normalmente é ouvida e percebida a respeito dos cultos afro-brasileiros através da visão estilizada e idealizada de cada compositor. Villa-Lobos praticamente cria e delinea esssa representação em sua música através da tópica canto de xangô, tirando-a do contexto original e colocando-a na música de concerto. 
- Assim, ao ser demonstrada neste e em outros trabalhos como uma convenção amplamente utilizada, esta ganha autonomia para ser chamada de tópica.

- Por fim, percebemos que a tópica interage com a estrutura da música, revelando processos composicionais que são essenciais para a música brasileira.

Ainda é possível continuar esta pesquisa em trabalhos posteriores, verificando a aparição e ocorrência do tipo xangô e da tópica canto de xangô em outras obras do repertório brasileiro. Como disse Renato Ortiz, "dizer que somos diferentes não basta, é necessário dizer em que nos identificamos" (ORTIZ, 2006, p.7). Os elementos afro-brasileiros analisados no presente artigo são um dos pontos em que nossa música se diferencia, e se forma. Então, torna-se indispensável pesquisar essa música, bem como possíveis significados e representações de elementos da cultura afro-brasileira dentro das composições. Ao identificar como se dão estas representações dentro da estrutura da música, a estrutura e o significado se correlacionam, e é também neste ponto que o estudo de significação se torna ainda mais importante para compreender nossa música e nossos processos composicionais, que não são compostos apenas elementos estruturais (como harmonia, ritmo, melodia, etc) de forma isolada do seu singificado. Reconhece-se, assim, as partes intrínsecas e formadoras da nossa cultura e da nossa música, reforçando a idéia de fusão cultural que permeia essa formação.

\section{Bibliografia}

ADOLFO, Sérgio Paulo. "O mito africano no cotidiano dos afro-brasileiros". In: SANTOS, Volnei Edson dos (Org.). Sopros do silêncio. Londrina: EDUEL, 2008.

AGAWU, Kofi. Music as discourse - Semiotic adventures in romantic music. New York: Oxford University Press, 2009.

Representing African Music: Postcolonial notes, queries, positions. New York: Routledge, 2003.

__-. Playing with signs: a semiotic interpretation of classic music. Princeton: Princeton University Press, 1991.

ANDRADE, Mário de. Ensaio sobre a música brasileira. 3.ed. São Paulo: Livraria Martins Editora, 1972.

ANGENOT, Marc. Glossário da crítica contemporânea 1. Lisboa: Comunicação. 1984.

CAMARA CASCUDO, Luiz da. Dicionário do Folclore Brasileiro, 12ª ed. São Paulo: Global, 2012. 
CANCLINI, Nestor Garcia. Culturas Híbridas: estratégias para entrar e sair da modernidade. 4. ed. São Paulo: UNESP, 2011.

CARVALHO, José Jorge de. “Estética da opacidade e da transparência. Mito, música e ritual no culto xangô e na tradição erudita ocidental". Série Antropologia, v. 108, 1991.

COELHO DE SOUZA, Rodolfo. "Hibridismo, Consistência e Processos de Significação na Música Modernista de Villa-Lobos". In: Ictus, v. 11, n. 2. Salvador: UFBA, 2010.

CORTEZ, Gustavo. SANTOS, Inaicyra Falcão dos. ANDRAUS, Mariana Baruco Machado. Corpo e ancestralidade: estudo dos rituais e mitos de origem afro brasileira no panorama da dança contemporânea brasileira. Rev. Cient. / FAP, Curitiba, v.7, p. 11 - 22, jan./jun. 2011.

FREIRE, Priscila Gambary. Dança brasileira e dança negra para piano solo de Camargo Guarnieri: Uma abordagem interpretativa. 2007. Dissertação de mestrado. Univerisidade Estadual de Campinas: Campinas.

GRABÓCZ, Márta. Musique, narrativité, signification. Paris: L'Harmattan, 2009.

HATTEN, Robert. Interpreting Musical Gestures, Topics, and Tropes: Mozart, Beethoven, Schubert. Bloomington: Indiana University Press, 2004.

Musical Meaning in Beethoven: Markedness, Correlation and Interpretation. Bloomington: Indiana University Press, 1994.

LYRIAN STUDIO TENDA. Camargo Guarnieri - "Dansa Negra”. Disponível em: <https://www.youtube.com/watch?v=INM-VCY7sw8>. Data de acesso: 15/abr/2016.

MACHADO NETO, Diósnio. "As imagens do músico caipira: ideias topificadas e tropificadas na consubstanciação de uma referência cultural paulista". In: 3 Congresso Nacional de Iconografia Musical, 2015, Salvador. Anais do 3ํ Congresso Brasileiro de Iconografia Musical. Salvador: UPBA, 2015. p. 149-162.

"O discurso musical no Requiem de Marcos Portugal através de um estudo comparativo das tópicas: circunstâncias históricas e contextos estilísticos". In: CRANMER, D. (Org.). Marcos Portugal: uma reavaliação. 1 ed. Lisboa: Colibri, 2012. p. 379-395.

MARUN, Nahim. Revisão crítica das canções para a voz e piano de Heitor Villas-Lobos publicadas pela Editora Max Eschig. São Paulo: Cultura Acadêmica, 2010.

MICHAELIS. Moderno dicionário da língua portuguesa. São Paulo: Editora Melhoramentos, 1998-2009. Disponível em: <http://michaelis.uol.com.br/moderno/ 
portugues/index.php>. Acesso em 5/mai/2016.

MONELLE, Raymond. The musical topic: hunt, military, and pastoral. Indiana University Press. 2006.

. The sense of music: semotic essays. Princeton University Press: New Jersey. 2000.

MOREIRA, Gabriel Ferrão. O elemento indígena na obra de Villa-Lobos: observações músico-analíticas e considerações históricas. 2010. Dissertação de mestrado. Universidade do Estado de Santa Catarina: Florianópolis.

MUNANGA, Kabengele. Uma abordagem conceitual das noções de raça, racismo, identidade e etnia. Palestra proferida no 30 Seminário Nacional Relações Raciais e Educação-PENESB- RJ, 05 nov. 2003. Disponível em: <http://www.ufmg.br/inclusaosocial/?p=59>. Acesso em: 4/mai/2016.

MUSEU VILLA-LOBOS. Villa-Lobos: sua obra: catálogo. Rio de Janeiro, 2010. 380p. Disponível em: <http://museuvillalobos.org.br/bancodad/VLSO_1.0.1.pdf >. Data de acesso: 15/abr/2016.

ORTIZ, Renato. Cultura brasileira \& identidade nacional. 5.ed. São Paulo: Brasiliense, 2006.

PAES, Priscila. A utilização do elemento afro-brasileiro na obra de Francisco Mignone. 1989. Dissertação em artes. Universidade de São Paulo: São Paulo.

PIEDADE, Acácio. "A teoria das tópicas e a musicalidade brasileira: reflexões sobre a retoricidade na música". El oído pensante, vol. 1, n. 1, 2013. Disponível em <http://ppct.caicyt.gov.ar/index.php/oidopensante>. Data de acesso: 10/jul/2015.

"Perseguindo fios da meada: pensamentos sobre hibridismo, musicalidade e tópicas". In: Per Musi - Revista Acadêmica de Música, n.23, p. 103-112. 2011. Disponível em < http://www.scielo.br/pdf/pm/n23/n23a12.> Acesso em 10/jul/2015. "Tópicas em Villa-Lobos: o excesso bruto e puro". In: SIMPOSIO INTERNACIONAL VILLA-LOBOS - USP. 2009. Disponível em: <http://disciplinas.stoa. usp.br/pluginfile.php/261789/mod_resource/content/1/Tópicas\%20em\%20Villa-Lobos\%20o\%20excesso\%20bruto\%20e\%20puro\%20\%28Piedade\%202009\%29. pdf>. Acesso em: 10/jul/2015. p.127-134.

PIEDADE, Acácio. BENKE, Ester. "Tópicas em Camargo Guarnieri: uma análise da Sonatina Nr. 1". In: Anais do XIX Congresso da ANPPOM. Curitiba, 2009.

PLESCH, Melanie. "Topic Theory and the Rhetorical Efficacy of Musical Nationalisms: the Argentine Case". In: PANOS, N., LYMPORIOUDIS, V., ATHANASOPOU- 
LOS, G., and NELSON, P. (org.). Proceedings of International Conference on Music Semiotics, in Memory of Raymond Monelle. Edinburgh: The University of Edinburgh/ IPMDS - International Project on Music and Dance Semiotics. 2013.

PLESCH, Melanie. "La música en la construcción de la identidad cultural argentina: el topos de la guitarra en la producción del primer nacionalismo." Revista Argentina de Musicología, pp. 57-68. 1996.

PRANDI, Reginaldo. VALLADO, Armando. Xangô, rei de Oió. In: AULO BARRETTI FIILHO. (org.). Dos yorùbá ao candomblé kétu. 1 ed. São Paulo: Edusp, 2010, v. 1, p. 141-161. Disponível em: http://www.fflch.usp.br/sociologia/prandi/xangorei.htm. Acesso em: 4/mai/2016.

RAMOS, Arthur. O negro brasileiro. 2 ed. São Paulo: Nacional, 1940.

RATNER, L. G. Classic music: Expression, form and style. New York: Schirmer Books, 1980.

RODRIGUES, João Barbosa. Poranduba Amazonense, ou kochiyma-uara porandub, 1872-1887. Rio de Janeiro: Typ. de G. Leuzinger \& Filhos. 1890. Disponível em: <http://biblio.etnolinguistica.org/rodrigues_1890_poranduba>. Acesso em: 24/ nov/2015.

SALLES, Paulo de Tarso. "National identity, modernity and other intertextual relations in the Ninth String Quartet of Villa-Lobos." In: PAWLOWSKA, Malgorzata and MALECKA, Teresa. Music: Function and Value: Proceedings of the 11th International Congress on Musical Signification, 27 IX - 2 X 2010, Kraków, Poland, Volume 1: 684697, 2013a.

"Villa-Lobos and Nationality Representation by Means of Pictorialism: Some Thoughts on Amazonas". In: PANOS, N.; LYMPORIOUDIS, V.; ATHANASOPOULOS, G.; and NELSON, P. (org.). Proceedings of the International Conference on Music Semiotics, in Memory of Raymond Monelle. Edinburgh: The University of Edinburgh/IPMDS - International Project on Music and Dance Semiotics. $2013 \mathrm{~b}$.

"A música de Villa-Lobos na semana de arte moderna de 22". In: Ladeira, M. E Belchior, P. Presença de Villa-Lobos: 100 Anos de Arminda, Rio de Janeiro: Museu Villa-Lobos, v. 14. 2012. p. 102-119.

"Análise do material harmônico nos compassos iniciais do Noneto de Villa-Lobos". Anais do XX Congresso da ANPPOM, Florianópolis: UDESC, 2010.

Villa Lobos: Processos composicionais. Campinas: Editora da Unicamp, 2009. 
Aberturas e impasses: O pós-modernismo na música e seus reflexos no Brasil - 1970 - 1980. São Paulo: Editora Unesp, 2005.

SANDRONI, Carlos. Feitiço decente: Transformações do samba no Rio de Janeiro (1917-1933). Rio de Janeiro: Jorge Zahar, 2001.

SANTOS, Moacir. Coisas: cancioneiro Moacir Santos. In: ADNET, Mario; NOGUEIRA, Zé. Rio de Janeiro: Jobim Music, 2005.

SEGATO, Rita Laura. Raça é signo. Série Antropologia, 2005. Disponível em: <http://pt.scribd.com/doc/16639751/raca-e-signo>. Acesso em: 4/mai/2016.

SODRÉ, Muniz. .A verdade seduzida por um Conceito de Cultura no Brasil. Rio de Janeiro: Codecri, 1983.

STEFANOVIC, Ana. "Once more on musical topics and style analysis: A critical examination of Agawu's analysis of the introduction to Beethoven's Pathetic Sonata". ZGMTH 7/3. Hildesheim: Olms S. 2010. p. 311-325.

TARASTI, Eero. Heitor Villa-Lobos: The life and Works, 1887-1959. Jefferson, North Carolina, and London: Mc Farland \&Company, Incl., Publishers, 1995.

VERHAALEN, Marion. Camargo Guarnieri: Expressões de uma vida. São Paulo: Imprensa Oficial, 2001.

\section{Juliana Ripke - Curriculum}

Mestranda em musicologia pela Universidade de São Paulo (ECA-USP) sob orientação do Prof. Dr. Paulo de Tarso Salles; bacharel em Piano pela Faculdade Cantareira sob orientação do pianista cubano Yaniel Matos; e tecnóloga em Piano popular pela Fundação das Artes de São Caetano do Sul. Estudou piano com o pianista David Berkman em Nova York (2013), e piano erudito na Escola Municipal de Musica de São Paulo no período de 2010 a 2013, onde participou de recitais em homenagem a grandes compositores brasileiros como Osvaldo Lacerda e Camargo Guarnieri. Atualmente, é professora de piano do curso preparatório da Faculdade Cantareira; pianista correpetidora dos corais do Instituto Baccarelli; realiza trabalhos como pianista com música instrumental brasileira e jazz; é pianista do quinteto instrumental de música brasileira "Jacatacamarajá" que se apresenta em Sescs, teatros, festivais e está gravando seu segundo CD. Como pesquisadora na área de 
teoria e análise musical, tem apresentado seus trabalhos e pesquisas em congressos nacionais e internacionais. 